\title{
A REDUÇÃO DA MAIORIDADE PENAL: UMA ANÁLISE DOS EDITORIAIS DO JORNAL O GLOBO
}

\section{THE REDUCTION OF CRIMINAL MAJORITY: AN ANALYSIS OF THE EDITORIALS OF THE O GLOBO NEWSPAPER}

\author{
Felipe da Veiga Dias \\ Faculdade Meridional - IMED - (Passo Fundo, RS, Brasil) \\ Marília De Nardin Budó \\ Universidade Federal de Santa Maria - UFSM - (Santa Maria, RS, Brasil) \\ Patrícia Silveira da Silva \\ Faculdade Meridional - IMED - (Passo Fundo, RS, Brasil)
}

Recebimento: 20 abr. 2018

Aceitação: 4 jun. 2018

\begin{abstract}
Como citar este artigo / How to cite this article (informe a data atual de acesso / inform the current date of access):
DIAS, Felipe da Veiga; BUDÓ, Marília De Nardin; SILVA, Patrícia Silveira da. A redução da maioridade penal: uma análise dos editoriais do jornal O Globo. Revista da Faculdade de Direito UFPR, Curitiba, PR, Brasil, v. 63, n. 2, p. 115-143, ago. 2018. ISSN 2236-7284. Disponível em: <https://revistas.ufpr.br/direito/article/view/59031>. Acesso em: 30 ago. 2018. DOI: http://dx.doi.org/10.5380/rfdufpr.v63i2.59031.
\end{abstract}

\section{RESUMO}

O tema deste trabalho é a representação midiática do tema da redução da maioridade penal, a partir do pressuposto de que os meios de comunicação são um meio de controle social informal. A partir da análise dos editoriais do jornal O Globo, buscar-se-á a compreender a maneira como o segundo jornal de maior circulação e tiragem do país, pertencente à maior empresa de comunicação, buscou influenciar a política a respeito do ato infracional. Adotou-se como marco temporal o ano da promulgação do Estatuto da Criança e do Adolescente (1990), até o mês de agosto de 2017, período em que foi realizada a presente pesquisa. O trabalho está estruturado em duas partes. Na primeira parte será apresentado como marco teórico a Criminologia Crítica e a Teoria da Proteção Integral, adotando a técnica de pesquisa bibliográfica. Na segunda parte serão apresentados os resultados da análise dos 46 editoriais do jornal O Globo sobre a maioridade penal, utilizando como metodologia de pesquisa a teoria fundamentada nos dados, com abordagem predominantemente indutiva. Após a análise conclui-se que a representação social do adolescente autor de ato infracional reproduziu estereótipos que o identificam como um inimigo da sociedade, não por acaso aparecendo a proposta de aumento da punição por meio do encarceramento precoce como a solução para o problema da violência. O tema da impunidade se sobressaiu, desconsiderando completamente as medidas socioeducativas e a principiologia de que se reveste o direito da criança e do adolescente.

\section{PALAVRAS-CHAVE}

Criminologia crítica. O Globo. Editoriais. Maioridade penal. 


\begin{abstract}
The theme of this work is the mediatic representation of the topic of the reduction of the criminal majority age, based on the assumption that the media is a means of informal social control. From the analysis of the editorials of the O Globo newspaper, it sought to understand how the second largest newspaper in circulation and printing in Brazil, belonging to the largest communication company, sought to influence the policy regarding the infraction. The year of the promulgation of the Child and Adolescent Statute (1990) was adopted as the time frame, until the month of August, 2017, when this research was carried out. The work was structured in two parts. In the first part it has been presented, as a theoretical framework, Critical Criminology and Theory of Integral Protection, under the technique of bibliographic research. The second part has presented the results of the analysis of 46 editorials of the $\mathrm{O}$ Globo newspaper on the criminal majority age, using as a research methodology the theory based on the data, with a predominantly inductive approach. After the analysis, it is concluded that the social representation of the adolescent author of an infraction act has reproduced stereotypes that identify him as an enemy of society, thus not coincidentally in line with the proposal of increased punishment through early incarceration as the solution to the problem of violence. The theme of impunity has stood out, completely disregarding the socio-educational measures and the principiology of the law of the child and the adolescent.
\end{abstract}

\title{
KEYWORDS
}

Critical criminology. O Globo. Editorials. Criminal majority age.

\section{INTRODUÇÃO}

A redução da maioridade penal tem sido pauta de numerosos jornais brasileiros a partir do surgimento do Estatuto da Criança e do Adolescente (ECA). A cada pânico moral decorrente de um ato infracional fortemente midiatizado, políticos dos mais diversos partidos apresentam as soluções ao problema, já rotulado como emergencial.

O presente trabalho busca compreender a maneira como os meios de comunicação - aqui especificamente a edição impressa do jornal O Globo - representam em seus editoriais o problema do ato infracional, suas causas e soluções. Considerando-se a mídia como forma de controle social informal, os editoriais aparecem como documento fecundo a informar práticas políticas com o objetivo de acalmar a sociedade amedrontada diante dos pânicos morais construídos pelos mesmos meios de comunicação.

A partir de pesquisa anteriormente realizada no jornal Folha de S. Paulo (BUDÓ, 2015), periódico que tem historicamente se declarado contrário à redução da maioridade penal, mas que aposta no aumento do prazo de internação como solução milagrosa ao ato infracional, este trabalho busca comparar os resultados com aqueles obtidos da análise dos editoriais do jornal O Globo. Este periódico, pertencente às Organizações Globo, pelo contrário, tem se posicionado favoravelmente àquela medida político-criminal. Resta compreender quais são as representações sociais do 
adolescente, do ato infracional e da resposta estatal que conduzem à adoção dessa postura pelo jornal, na comparação com a Folha.

O critério adotado para a escolha do jornal foi sua posição enquanto jornal de maior circulação impressa e digital no País, conforme classificação da Associação Nacional de Jornais (ANJ) (2017).

Para atingir esse objetivo serão analisadas as estruturas das propostas e os discursos midiáticos para o recrudescimento do controle de adolescentes em conflito com a lei. A questão que orienta a pesquisa foi assim formulada: quais são os mecanismos argumentativos utilizados pelo jornal O Globo na construção do problema da violência e da solução proposta na Câmara dos Deputados, a partir das representações do adolescente, do ato infracional e da resposta estatal?

O trabalho está estruturado em duas partes. Na primeira será apresentado como marco teórico a Criminologia Crítica e a Teoria da Proteção Integral, adotando como técnica de pesquisa a revisão bibliográfica. Na segunda parte serão apresentados os resultados da análise dos editoriais do jornal O Globo sobre a maioridade penal, utilizando como metodologia de pesquisa a teoria fundamentada nos dados, com abordagem predominantemente indutiva. Os dados analisados foram obtidos a partir de busca no acervo do jornal O Globo com o termo "redução da maioridade penal”. Adotou-se como marco temporal inicial o ano da promulgação do Estatuto da Criança e do Adolescente (1990) e cobriu-se até o mês de agosto de 2017, quando foi realizada a presente pesquisa, obtendo-se 46 editoriais.

\section{INFÂNCIA, CRIME E MÍDIA: ENTRE O RECONHECIMENTO E A EXCLUSÃO}

Apesar de a história da infância mostrar que a compreensão dessa fase da vida humana como um período de desenvolvimento é bastante recente (ARIÉS, 1981), na contemporaneidade existe um consenso científico sobre sua peculiaridade, o que a torna merecedora de atenção diferenciada. No Brasil, a partir de 1988 adotou-se como base para os direitos de crianças e adolescentes a teoria da proteção integral, a qual foi resguardada nos principais textos jurídicos nacionais, como a Constituição e o Estatuto da Criança e do Adolescente. Nas palavras de Costa (2012, p. 131), a proteção integral "[...] é a responsabilização dos adultos pelo cuidado e garantia de condições para que crianças e adolescentes possam exercer sua cidadania, com dignidade”. Trata-se do nascimento 
de um novo campo no Direito, ao recepcionar a lógica de que crianças e adolescentes são sujeitos de direitos e não meros objetos de tutela (VERONESE, 2012, p. 60).

O reconhecimento de um status jurídico, porém, não é capaz de modificar as bases sociais e econômicas - consequências do modelo capitalista - nas quais estão inseridas crianças e adolescentes. É necessário reconhecer que a histórica diferenciação entre as infâncias em função da classe social, das relações de gênero e raciais proporcionam o que Rizzini e Barker (2004, p. 138) nomeiam como verdadeiras segregações nas grandes cidades. Com espaços restritos destinados às camadas da classe média ou alta, além da guetização sofrida pela população negra, impedem qualquer espécie de interação entre crianças de classes sociais diferentes.

Outro dado que expõe as fragilidades na garantia de direitos à infância são os altos índices de mortalidade, os quais se apresentam concentrados na população jovem, entre quinze e vinte e nove anos, especialmente homens negros, já que os estudos revelam clara desproporção quando comparados os homicídios de brancos e negros no País (WAISELFISZ, 2016). A exclusão social não se dá apenas com a eliminação total dos sujeitos indesejados, mas também pelos abusos de outras ordens: o Brasil apareceu na pesquisa de 2016 da organização Save the Children como o pior país da América do Sul para ser menina. Alarmantes índices em todos os problemas centrais da pesquisa, como a baixa representatividade política, casamento na infância ou mesmo o baixo índice de conclusão do ensino médio deram origem a essa classificação (SAVE THE CHILDREN, 2016).

Esta "guerra" instalada não é contra a pobreza e sim contra os pobres, buscando a responsabilização destes pelos problemas sociais enfrentados (construção de bodes expiatórios), sendo que tal ocorrência é verificável em outros países (WACQUANT, 2007, p. 96). Os componentes fáticos denunciam as marcas de um processo de construção de discursos punitivos contra crianças e adolescentes, em especial quando estes são negros, residem em áreas de periferia ou tão somente pertencem às classes sociais mais pobres. No caso brasileiro, está em marcha o que Flauzina (2008) nomeou de um projeto genocida de Estado, que conduz suas práticas ao extermínio da população negra. Para além dos números que atestam a preferência pela “carne negra” na gestão penal da pobreza, as próprias páginas dos jornais mostram nas fotografias quem são os corpos descartáveis. Fotografias tiradas pelas costas mostrando negros torsos nus, fotografias frontais com olhos borrados, fotografias em que os meninos são carregados como sacos por policiais brancos ferozes (BUDÓ, 2013). Se no discurso midiático as relações raciais são diariamente invisibilizadas, não há nada mais visível do que a mensagem transmitida pelos ícones a ilustrarem-no.

A dinâmica punitiva contra crianças e adolescentes não pode ser compreendida com a observação somente de seus efeitos atuais, visto que alguns dos fundamentos interventivos remontam 
discursos oriundos do pensamento menorista, o qual ainda via no infante um mero objeto de intervenção. Forçoso conectar a visão menorista com o positivismo criminológico claramente atravessado pelo racismo e eurocentrismo: aí se intersecionam as falas punitivas imbuídas do afã de “curar” para com isso "salvar a nação”. Para tanto, passa-se a criminalizar diversas condutas realizadas por crianças e adolescentes, desde a prática da capoeira até a vadiagem (CUSTÓDIO, 2009, p. 15), e permitindo a legalidade de sua institucionalização. Tais infrações eram claramente dirigidas ao controle social dos descendentes de escravos libertos, abandonados à própria sorte com a abolição, e então consolidados como um dos maiores pavores da minoria branca da república nascente.

Estendem-se durante largo período histórico brasileiro as falas de restrição e punição dos infantes, mas não necessariamente ligando-os com práticas delitivas. Aa ações violentas de coerção estavam “justificadas” pela base jurídica do “menor”, a qual permitia a atuação policial e judicial com as institucionalizações "simplesmente porque eram pobres e destituídos das condições básicas de exercerem seus poderes políticos e terem uma vida digna, como deveria ser o direito de toda a criança” (CUSTÓDIO, 2009, p. 22).

Nisso reside a visão higienista (ANITUA, 2006, p. 141-142), buscando com tal linha interventiva delimitar uma relação direta entre infantes determinados e práticas delitivas, em referência direta à lógica determinista etiológica (PAVARINI, 2002, p. 44).

Os danos produzidos por esse raciocínio supramencionado são sentidos diretamente na seara da criança e do adolescente até os dias de hoje. Demonstração disso se dá por meio de posturas ainda presentes no Judiciário na seara da infância, quando estas apresentam muitas vezes posições menoristas travestidas pela proteção integral, utilizando-se como base decisória o "bom senso" ou mesmo a necessidade de "punir" o adolescente em um ato infracional, rememorando em todas elas as práticas paternalistas punitivas usuais do Juiz de Menores (ROSA, 2005, p. 18-19).

Como exemplo dessas posturas ainda presentes no Judiciário, tem-se a etnografia feita pela antropóloga Paula Miraglia (2005) nas Varas Especiais da Infância e da Juventude em São Paulo. Durante as audiências observadas, a antropóloga constatou que os magistrados que atuaram nas audiências determinavam seu andamento, não garantindo espaço para a ampla defesa e o contraditório, tampouco para ouvir o/a adolescente, com uma postura claramente paternalista (MIRAGLIA, 2005).

Essa atuação aparece não somente por aplicar subterraneamente a doutrina menorista na seara da infância, mas igualmente por perpetuar todas as interpretações criminológicas positivistas, as quais têm como efeito a manutenção dos processos (e discursos) de exclusão social e discriminação. 
A manutenção desses fundamentos excludentes gera a duplicidade no tratamento dos direitos da criança e do adolescente, de um lado a criança ou adolescente inocente como vítima, de outro aquele de "natureza” má, o qual é uma “ameaça precoce à sociedade” (BUDÓ, 2013, p. 46). E isso leva à manutenção e reprodução de estereótipos, sem atentar à teoria da proteção integral como matriz da infância e tampouco a limitação imposta por um raciocínio maniqueísta (bom/mau vítima/bandido).

O pensamento binário criado para interpretação da infância no País logicamente ancora-se em discursos, oficiais e não oficiais, os quais sedimentam essa percepção. Neste encaixe encontra-se a importância da relação entre mídia e crime, pois tal conexão aprofunda-se quando se debruça sobre as construções sociais realizadas pela seletividade (seja da notícia ou do sistema penal) (BUDÓ, 2015).

Esse incremento na dimensão tomada pela notícia já era advertido por Bourdieu ao apontar para a seleção de determinadas situações, sendo que elas devem sempre representar algo sensacional, ou seja, tomam-se casos pontuais, dá-se a eles dimensões exageradas e trágicas a fim de causar uma reação do público e, por conseguinte, um incremento na audiência com imagens, palavras e discursos igualmente extraordinários (BOURDIEU, 1997, p. 25-26).

Objetiva-se em muitas dessas representações da “realidade” trazer ao público a inflamação típica do medo irracional (e desproporcional), algo que remete diretamente às construções de pânico moral. Por meio dessa estratégia almeja-se tanto alvos novos quanto recorrentes: independentemente de qual seja a imputação, o importante é causar, a partir de um episódio ou de um indivíduo ou grupo, uma definição de ameaça a todas as bases e valores sociais definidos (COHEN, 2002, p. 1). Porém, apesar da possibilidade de esquecimento do pânico causado, no caso da relação entre crimes e infantes o que se consolida é uma reativação simbólica e oportuna a cada nova onda punitivista (BUDÓ, 2013).

Ademais, o pânico moral instala-se com fulcro na noção de que o ato desviante é dependente da reação social provocada, motivo pelo qual se instiga uma reação exagerada a determinadas condutas. Juntamente a isso adiciona-se o componente de quem realiza o ato desviante, porque a reação depende igualmente do sujeito que realiza e as pessoas que se sentem prejudicadas, algo que já restou evidenciado em estudos sobre a delinquência infanto-adolescente (BECKER, 2008, p. 2425). Desse modo “os pânicos morais se acendem com a morte de pessoas que correspondem à figura da 'vítima ideal', bem como o ofensor se caracteriza como o agressor ideal” (BUDÓ, 2015, p. 98). Como nota Zaffaroni (1991), as campanhas midiáticas de lei e ordem que ocorrem quando o poder do sistema penal está ameaçado não seriam possíveis sem os meios de comunicação de massa: 
Estas campanhas realizam-se através da "invenção da realidade” (distorção pelo aumento de espaço publicitário dedicado a fatos de sangue, invenção direta de fatos que não aconteceram), "profecias que se auto-realizam” (instigação pública para a prática de delitos mediante metamensagens de "slogans" tais como a "impunidade é absoluta", "os menores podem fazer qualquer coisa”, "os presos entram por uma porta e saem pela outra”, etc.; publicidade de novos métodos para a prática de delitos, de facilidades, etc.), "produção de indignação moral” (instigação à violência coletiva, à autodefesa, glorificação de “justiceiros”, apresentação de grupos de extermínio como “justiceiros”, etc.) (ZAFFARONI, 1991, p. 129).

O padrão estabelecido por abordagens de pânico ou mesmo recrudescimento penal encaixam-se no que Pratt (2007) denomina de populismo penal, em que as vítimas da criminalidade compreendem-se como prejudicadas pela permissividade jurídica. Isso alimentaria a raiva e a desilusão com o sistema penal, em uma inversão de prioridades (há uma releitura do “nós” versus “eles”). A partir disso, alimenta-se um incremento punitivo com base, especialmente, em "sensações e intuições”, muito mais do que em dados ou no estudo da realidade (PRATT, 2007, p. 12-13).

Para caracterizar o modelo criminológico no qual o discurso punitivo dos meios de comunicação se embasa, Zaffaroni (2012) elaborou o conceito criminologia midiática. Contrapondose ao conhecimento acadêmico construído pelos estudos da criminologia, a criminologia midiática cria a realidade por meio de notícias (com informações, desinformações ou subinformações) determinadas, em flagrante convergência com os estereótipos delimitados, bem como na simplificação dos fatos e em relações de causalidade mágicas (ZAFFARONI, 2012, p. 303).

O foco da criminologia midiática é a transmissão da mensagem, já que se almeja criar uma realidade de boas pessoas (cidadão de bem) contra a gama de criminosos, a qual pode ser identificada por meio de estereótipos/estigmas, e que é sempre considerada má em suas aspirações (ANDRADE, 2012, p. 166).

Exemplificação disso seria a associação de comportamentos e estereótipos para antecipar o processo de exclusão, ou seja, ao observar um adolescente de um bairro pobre e que está tomando uma bebida ou mesmo fumando maconha, a projeção deve ser que "amanhã fará o mesmo que o parecido que matou uma velhinha na saída de um banco e, portanto, é preciso isolar a sociedade de todos eles” (ZAFFARONI, 2012, p. 307). Portanto, a noção de segurança pública, inclusive projetada midiaticamente, direciona-se com base na criminalidade tradicional que ocorre em locais públicos, bem como associa-se ao medo com determinados estereótipos, ou seja, como se existisse uma repartição clara de papéis entre agressor e vítima, igualmente apartados em grupos sociais respeitáveis e marginalizados (BARATTA, 2004, p. 157-158). 
O clamor punitivo alimentado pela mídia é seletivo, pois as crianças e adolescentes alvos desse incremento coercitivo são os filhos dos “outros”, e não os filhos daqueles que têm boas condições de renda e status social, ou seja, o público a ser atingido são os infantes pobres, que vivem na favela, ou cujos pais já estão encarcerados. Além da seletividade inerente ao sistema penal, há um descompasso com a solidariedade na dor alheia, visto que casos que demonstram as falhas no sistema de proteção dos direitos de crianças e adolescentes (como as situações vividas por Eloá ou João Hélio) são transmutados em processos de dramatização e histeria coletiva, a fim de com isso alimentar o anseio por "justiça” (que em prática significa vendeta), e alterar o próprio significado da mídia, que passa a ser uma agência punitiva com o veredito antecipado: condenação (BATISTA, 2002).

O viés criminológico midiático é alicerçado em discursos não científicos para se sustentar e, no tocante às demandas contra a infância, isso não é diferente. Aponta-se, por exemplo, para o apelo ao senso comum do tipo "todos sabemos que [...]", sendo exatamente o que se traz em visões como a da "teoria da cópia do crime”, ou seja, a ignorância de que a maior parte dos discursos do senso comum são basicamente desconexões da ciência e da não ciência, nada mais que disfunções fragmentadas e incoerentes que pregam verdades universais sustentadas em mitos específicos, bem como em uma cultura particular em um determinado espaço de tempo (JEWKES, 2004, p. 12).

Esse aspecto é importante para a compreensão de como são fundamentados os discursos contra a infância. Esses discursos aparecem não apenas no sentido do resgate histórico dos preconceitos contra o "menor”, apesar da massiva doutrina na seara da infância alertar sobre o teor pejorativo dessa expressão e sua consequente abolição após o texto constitucional de 1988 (LAMENZA, 2011, p. 11). Aparecem também na direção do reforço dos “especialistas” na seara da segurança pública, os quais apontam para os mais jovens como o grande problema da criminalidade.

Nesse sentido, geram-se do mesmo modo que a simplificação dessa realidade as respostas fáceis ou mágicas para a questão da criminalidade na infância, já que a mídia se alimenta tanto de ondas de crime quanto de soluções, ou melhor, de curas "milagrosas" para a criminalidade. Importante dizer que tais remédios prolatados pelos meios de comunicação objetivam o incremento na produção de notícias em unidades pequenas, simples e segmentadas (YOUNG, 2002, p. 189-190).

No caso da relação delimitada pelos meios de comunicação entre crimes e infantes existem apenas duas soluções: a) a primeira é considerada mais branda e prevê “apenas” o endurecimento das medidas socioeducativas; enquanto b) a segunda linha de atuação determina a redução da maioridade penal como suposta solução ao problema da criminalidade. Por óbvio que essa linha de raciocínio exclui os posicionamentos extremistas e sem qualquer ligação com os fundamentos jurídicos 
nacionais; mais precisamente, não são consideradas as propostas aberrantes de pena capital ou mesmo de encarceramento perpétuo.

As duas proposições demandam modificações legais, haja vista o entendimento já reconhecido de que a lei é utilizada como instrumento de poder e que, assim, não serve apenas para representar interesses dos grupos dominantes, mas também para conservar o próprio poder (PAVARINI, 2002, p. 138). Reflete-se nesse tipo de disposição a visão de inimigo social dirigida a crianças e adolescentes determinados, os “menores”, pois o "grau de periculosidade do inimigo - e, portanto, da necessidade de contenção - dependerá sempre do juízo subjetivo do individualizador, que não é outro senão o de quem exerce o poder” (ZAFFARONI, 2007, p. 25).

Na primeira proposição vislumbram-se usualmente equívocos básicos na interpretação dos direitos da infância, pois tais alterações em geral aludem à semelhança entre as infrações penais e os atos infracionais, como se ambos os sistemas operassem da mesma forma, em uma espécie de direito penal juvenil. Esse deslize apresenta a fragilidade da fundamentação legislativa sobre a matéria, a qual trabalha com uma ótica completamente distinta do universo criminal, de maneira a afastar-se da visão tutelar e de coisificação dos infantes, e encaminhando-se para a proposta de intervenção infracional com base na responsabilização social e pedagógica (VERONESE, 2015, p. 94).

Demonstração do endurecimento das medidas constata-se na atual tendência de reavivar as posturas positivistas (patológicas) e manicomiais contra adolescentes, como no caso denunciado das Unidades Experimentais de Saúde, as quais realizam uma passagem daqueles que não mais podem cumprir a medida de internação - seja por prazo ou por idade - e são realocadas por meio de alegações de transtornos de personalidade ou quanto à sua periculosidade por parte do Ministério Público que realiza a sua interdição civil. Ressalta-se a violação de direitos e o punitivismo de tal conduta, pois inexiste qualquer prazo de reavaliação da situação desses seres humanos “ou a definição de equipes incumbidas de promovê-la estão [sic] previstas, de modo que a característica que se sobressai desses processos de interdição” é nada mais do que a restrição da liberdade por tempo indeterminado, constituindo uma punição - até mesmo - perpétua (BUDÓ, 2013, p. 97).

A segunda perspectiva é a redução da maioridade penal. Embora a análise posterior se debruce sobre a mídia em específico nesse debate, cabe mencionar que, em estudo recente, Cappi constatou que, nos discursos parlamentares que defendem a manutenção da idade penal atual, são encontradas argumentações alinhadas ao pensamento repressivo e punitivo da infância, conforme assevera:

Três argumentos encontrados neste grupo de discursos fortalecem esta hipótese: (i) o Estatuto da Criança e do Adolescente já oferece uma resposta punitiva adequada, fazendo prova de 
uma “justa severidade”; (ii) é preciso aumentar a duração legal da privação de liberdade; e, por fim, (iii) é necessária a adoção de medidas punitivas contra os adultos que, de alguma maneira, contribuem para a delinquência juvenil (CAPPI, 2014, p. 24).

Depreende-se da constatação acima que, embora tenha se estabelecido uma base crítica de análise da infância e suas associações com a criminalidade, isso não significa o afastamento da seriedade metodológica imperiosa à apreciação dos discursos midiáticos sobre crianças e adolescentes, em especial àqueles que expõem a redução da maioridade penal em grandes veículos de comunicação.

Passa-se ao estudo específico dos editoriais do jornal O Globo, para que somente após a apreciação dos discursos utilizados seja possível apresentar as considerações acerca dos argumentos e posicionamentos no tocante à redução da maioridade penal.

\section{ANÁLISE DOS EDITORIAIS DO JORNAL O GLOBO DE 1990 A 2017}

Para a análise dos editoriais do jornal O Globo, adotou-se como marco temporal inicial o ano da promulgação do Estatuto da Criança e do Adolescente (1990), alcançando-se até o mês de agosto de 2017. A definição dos editoriais a serem analisados foi determinada com base na busca por palavras-chave no sítio eletrônico do acervo do jornal, tomando os termos "maioridade penal”, inseridos no campo "todas as palavras”.

Dentre os diversos resultados ocorridos com a pesquisa com o uso das palavras-chave, foram descartadas as notícias e demais parcelas do jornal que não se tratava de editoriais. O editorial é um tipo de matéria jornalística do gênero opinativo. Por representar a opinião institucional do jornal, ela não vem assinada. Como nota Alves Filho (2006), a impessoalização é uma das características dos editoriais como publicados geralmente no Brasil. Assim, apesar de trazerem forte conteúdo opinativo, fazem uso de estratégias que conduzem à função enunciativa de negar subjetividade ao texto (ALVES FILHO, 2006, p. 84-85), como se as afirmações ali contidas fossem meras constatações da realidade. Em trabalho anterior, de análise do jornal Folha de S. Paulo, mostrou-se como tais características se aplicam claramente àquele jornal (BUDÓ, 2015). Em O Globo não é diferente, conforme os resultados apresentados a seguir.

A amostra obtida foi de 46 editoriais. Uma vez que o posicionamento do jornal é expresso, no sentido favorável à redução da maioridade penal, o objeto da análise ficou concentrado nas representações do adolescente infrator, do ato infracional e das justificações à resposta estatal centrada na proposição de redução da maioridade. 
Com a ilustração do gráfico 1, é possível observar os períodos no quais houve um maior número de editoriais sobre o tema.

Gráfico 1. Quantidade de editoriais publicados por ano pelo jornal O Globo.

14

12

10

8

6

4

2

0

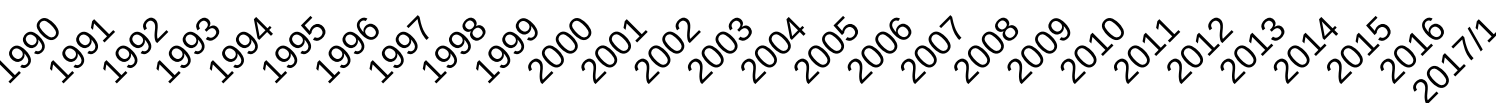

—Editoriais publicados por ano pelo jornal O Globo

Fonte: elaboração própria a partir do acervo do jornal O Globo.

A partir do que foi considerado na seção anterior sobre os pânicos morais envolvendo atos infracionais, o gráfico acima confirma a hipótese apresentada. Os anos em que há picos de editoriais são aqueles em que casos de grande repercussão envolvendo adolescentes tomaram as manchetes dos jornais.

Os períodos com mais publicações são os referentes à morte de Liana Friedenbach e Felipe Caffé, por um grupo de quatro adultos e um adolescente, conhecido como Champinha, em novembro de 2003 (seis editoriais), e à morte do menino João Hélio, de seis anos, que foi arrastado por sete quilômetros preso ao cinto de segurança do carro de sua mãe quando ele estava sendo roubado por quatro jovens adultos e um adolescente em fevereiro de 2007 (nove editoriais). Mais recentemente, ocorreu a morte do jovem Victor Hugo Deppman em um assalto praticado por um adolescente de 17 anos em abril de 2013 (quatro editoriais).

Conforme a análise realizada a respeito do jornal Folha de S. Paulo anteriormente, é necessário destacar que também O Globo repercutiu casos em que as vítimas facilmente poderiam ser reconhecidas na categoria do que Christie (1986) chamou de "vítima ideal”": "todas brancas e de

\footnotetext{
${ }^{1}$ Nils Christie (1986, p. 18) descreve a vítima ideal como "uma pessoa ou uma categoria de indivíduos que - quando atingidas por um crime - mais prontamente recebem o status completo e legítimo do status de ser uma vítima”. Para chegar a ser a vítima ideal, o caso deve preencher seis atributos: 1. A vítima é fraca em relação ao ofensor (mulheres,
} 
classe média ou alta. Os agressores, todos negros e moradores das periferias e favelas. Os locais, São Paulo e Rio de Janeiro” (BUDÓ, 2015).

As propostas de redução da maioridade penal têm vindo a público de maneira cíclica, geralmente obedecendo a um padrão: um adolescente pobre, negro e periférico é acusado de vitimizar - com violência e causando a morte da vítima - uma pessoa facilmente enquadrada no estereótipo de vítima - crianças, mulheres, brancas e de classe social média ou alta. Os meios de comunicação repercutem em detalhes o caso. Marchas acontecem nas cidades, exigindo justiça, o que implica criticar o Estatuto da Criança e do Adolescente sob a chave interpretativa da impunidade. Legisladores, sedentos por capital simbólico, protocolam propostas de alteração do Estatuto e da Constituição. As propostas chegam a ser objeto de deliberação em comissões, mas não são aprovadas pelo plenário, principalmente em função do arrefecimento das notícias.

Esse padrão foi rompido, contudo em 2015, ano em que o maior número de editoriais sobre o tema foi publicado por O Globo: foram treze editoriais. Nesse ano, vários desses editoriais tiveram como mote a colocação em pauta da PEC 171/1993 (BRASIL, 1993)² pelo então presidente da Câmara, Eduardo Cunha. A atitude de trazer à deliberação esta proposta não seguiu a ordem acima descrita: nenhum caso de grande repercussão estava ocupando as páginas dos jornais. A pauta mais forte nesse momento era o do debate político no pós-eleições de 2014. No parlamento eleito predominaram personagens conhecidos pelo seu conservadorismo, e pela oposição à presidenta eleita, Dilma Rousseff. A pauta da redução da maioridade penal foi historicamente objeto de contestação pela esquerda brasileira, em especial pelo Partido dos Trabalhadores, ao qual pertencia a então chefe do Executivo, já em seu segundo mandato. Dois casos de grande repercussão que aconteceram, respectivamente, em abril e maio de 2015 foram posteriores à atenção ao tema conferida pelo jornal e pela Câmara dos Deputados.

De uma maneira geral, todos os editoriais partiram do pressuposto básico de que existe um aumento da "delinquência juvenil”, ocasionada principalmente pela impunidade dos adolescentes, e, por isso, a resposta mais adequada seria o “combate à impunidade” por meio da alteração dos limites da imputabilidade penal pela idade. Mas para além dessa fórmula geral, há categorias específicas

crianças, doentes, velhos, p. ex.); 2. A vítima está realizando seu trabalho normal do dia-a-dia ou agindo virtuosamente; 3. A vítima é inocente pelo que aconteceu; 4. A vítima não está ligada nem sequer conhece o estranho que cometeu o crime; 5 . O criminoso é grande e mau; 6 . A vítima tem a combinação exata de poder, influência ou simpatia para alcançar com sucesso o status de vítima, sem ameaçar fortes interesses estabelecidos”.

2 A PEC 171/1993 reduz a maioridade penal de 18 para 16 anos nos casos de crimes hediondos, com exceção ao crime de roubo qualificado, tortura, tráfico de drogas e lesão corporal grave. Essas exceções foram incluídas por uma emenda à PEC, no dia seguinte à sua não aprovação (BRASIL, 1993). 
encontradas e que auxiliam na compreensão da postura do jornal e de sua intenção de influenciar não apenas cidadãos e cidadãs comuns leitores do texto, mas também a própria política.

\subsection{A (VELHA) QUESTÃO DISCERNIMENTO}

Sobre a caracterização do adolescente autor de ato infracional, muitas vezes foi mencionado nos editoriais que esse adolescente sabe distinguir o certo do errado, inclusive antes mesmo dos 16 anos, e a consequência direta desse argumento é que o discernimento conduziria à imputabilidade penal (O GLOBO, 2003a). Esse possível discernimento estaria relacionado à possibilidade de voto facultativo a partir dos 16 anos e também ao fácil acesso à informação ${ }^{3}$. Ter consciência para votar também possibilitaria ter a capacidade para escolher cometer, ou não cometer, atos infracionais. No editorial de 15 de novembro de 2003, logo após a morte do casal Felipe e Liana, o jornal afirmou “Mais ainda: quem nessa idade não soubesse que é errado matar, e que o criminoso deve pagar por seu crime, já seria caso perdido” (O GLOBO, 2003a).

Este não é um argumento novo, sendo central historicamente também nos debates parlamentares sobre a redução da maioridade penal (CAPPI, 2014) e na própria história do tratamento penal conferido a adolescentes na origem da república brasileira. A imputabilidade penal, segundo o código penal republicano, dependia justamente do juízo sobre o discernimento realizado pelo juiz da vara criminal, como pode ser lido em Budó (2013).

\subsection{POBREZA COMO UMA DAS CAUSAS ESTRUTURANTES DA VIOLÊNCIA}

Em várias oportunidades ficou clara a identificação de quem é o adolescente a ser considerado um perigo pelo jornal. A partir da relação direta, estabelecida nos editoriais, entre pobreza e criminalidade, o inimigo a temer é o adolescente pobre. Ao buscar as causas para o que é qualificado pelo jornal como “a ineficácia do Estatuto da Criança e do Adolescente desde a sua vigência”, em decorrência do aumento de adolescentes envolvidos nas estatísticas criminais, o jornal diagnostica "uma guerra na juventude, principalmente na pobre e masculina” (O GLOBO, 2003e, p.

\footnotetext{
${ }^{3}$ No editorial intitulado “Além da idade”, o jornal afirma que o adolescente atinge a maioridade mais cedo, e que isso seria característica de um mundo globalizado (O GLOBO, 2003b).
} 
6). Claramente aparece a identificação de que há maior envolvimento de adolescentes homens com o cometimento de atos infracionais em comunidades pobres.

Essa relação aparece declaradamente com o objetivo de tratar a partir de um ponto de vista preventivo, chamando o poder público à responsabilidade. Na prática, contudo, é possível identificar a velha leitura da Funabem, que identifica pessoas pobres como incapazes de cuidar dos próprios filhos, desencadeando práticas estatais autoritárias. No editorial intitulado “Com realismo”, publicado no dia 24 de fevereiro de 2007, dias após a morte do menino João Hélio, o jornal menciona que a falta de políticas públicas e de apoio familiar seriam algumas das causas do envolvimento dos adolescentes com o mundo do crime.

A falta de uma política nacional séria de planejamento familiar, potencializada pelas deficiências no sistema de ensino público e no aparelho de segurança, povoou as cidades de crianças e jovens sem qualquer perspectiva de vida, presas fáceis da cooptação por quadrilhas que se fortaleceram nas favelas e comunidades pobres em geral (O GLOBO, 2007d, p. 6).

Tudo se passa como se somente nas comunidades pobres houvesse o envolvimento de adolescentes com atos infracionais. Nesse trecho também foi possível reconhecer o adolescente infrator como vítima de uma sociedade falha em políticas públicas, e essa falha resultaria no seu envolvimento com atos infracionais.

Como causa da violência e da insegurança pública, no editorial "Sem meio-termo”, de junho de 2007, o jornal volta a afirmar que "a pobreza, a educação deficiente e os gastos sociais sem foco são as causas estruturais da violência” (O GLOBO, 2007f, p. 6). O jornal mencionou que a pobreza e as falhas das políticas públicas são as causas estruturais da violência, pois apenas o adolescente desprovido de educação é capaz de ser infrator. O jornal também afirma que a “pobreza extrema é uma indutora da violência” (O GLOBO, 2015b, p. 16).

Essa relação remete à doutrina da Situação Irregular, na qual o adolescente pobre era considerado infrator e, em decorrência disso, deveria ser tutelado pelo Estado. Essa relação “era imaginada com base em preconceitos e estereótipos e depois restava aos agentes do Estado enquadrar o público perfeito à caracterização da barbárie” (CUSTÓDIO, 2008, p. 25). Esse mesmo discurso é repetido nos editoriais “Sem meio-termo”, “Revisão necessária”, “Limite Irreal” e “Debate sobre criminalidade juvenil está fora de foco”. A violência, contudo, jamais é problematizada em sua forma efetivamente estrutural, aquela conceituada por Galtung (1969) como a repressão das necessidades humanas fundamentais. A reificação da questão da violência como sendo o resultado de ações individuais desconhece a situação de violência sofrida pelos adolescentes em situação de pobreza, muito mais grave, generalizada e potencialmente assassina. 
Com esse discurso de “pobreza como causa da criminalidade” é possível perceber que há uma "punição" relativa à classe social dos adolescentes, eis que todos praticam atos infracionais, mas apenas alguns são responsabilizados e etiquetados como criminosos (SANTOS, 2000). O jornal apenas reproduz a seletividade já facilmente visualizada na população recrutada para integrar os centros socioeducativos.

Outra característica do jornal que corrobora com o menorismo, é não utilizar termos técnicos e utilizar termos pejorativos para referir-se ao adolescente infracionalizado, como, por exemplo: “delinquente”, "bandido”, “criminoso” e "menor”". Um detalhe, que merece destaque, foi o uso do termo "monstro" para referir-se ao Champinha, no caso envolvendo a morte do casal Felipe e Liana. O jornal mencionou que o Estatuto ajuda a criar "monstros” (O GLOBO, 2003a, p. 6). Em algumas vezes foi irônico ao referir-se à nomenclatura determinada pela lei. Ao utilizar a palavra "apreensão" para o adolescente apreendido pela polícia, muitas vezes empregou o uso de aspas na palavra e ironizou o termo com a frase: “jargão politicamente correto” (O GLOBO, 2015a, p. 18). Ao aplicar essa frase, o jornal banalizou a separação do direito penal e do direito infracional, trazendo à tona a defesa de um direito penal juvenil.

Apesar da promulgação do ECA, foi possível observar a presença do menorismo nos editoriais do jornal, como forma de estereotipar o adolescente pobre como infrator e reproduzir a seletividade já existente na sociedade. A identificação das causas do problema como ligadas à ausência vaga de políticas públicas permite a delimitação do foco, sobre a definição de quem são os criminosos, nos adolescentes pobres.

\subsection{O ESTATUTO A FAVOR DA CRIMINALIDADE}

O jornal mencionou em todos os seus editoriais o aumento do envolvimento dos adolescentes com atos infracionais e o aumento de apreensões como ponto de partida de seu percurso argumentativo. Especificamente no segundo editorial analisado, de 2001, o jornal traz alguns dados da Delegacia de Proteção à Criança e ao Adolescente sobre as apreensões nos últimos cinco anos. Os atos infracionais citados são aqueles de rua, como os equiparados aos crimes de furto, roubo, tráfico de drogas e porte de arma (O GLOBO, 2001, p. 6). É também denunciada pelo jornal a quantidade de adolescentes recrutados pelos traficantes. Na argumentação do editorial, esse recrutamento resulta em impunidade, pois adolescentes supostamente não são punidos, por serem inimputáveis, e, em

\footnotetext{
${ }^{4} \mathrm{O}$ termo "menor" foi abolido pelo ECA, pois as crianças e os adolescentes não são mais objetos que precisam ser tutelados, mas são sujeitos de direitos (VERONESE; RODRIGUES, 2001, p. 35).
} 
decorrência disso, o jornal apresenta, em tom de revelação, que o ECA estaria incentivando a criminalidade (O GLOBO, 2007e, p. 3).

Desde o segundo editorial os atos infracionais citados são sempre os mesmos, sempre presente a menção do aumento dos atos infracionais e das apreensões dos adolescentes. Como visto, à exceção do ano de 2015, em regra foram casos graves e de grande repercussão que motivaram os editoriais e a atuação do jornal como empreendedor moral. No ano de 2015, a principal motivação para tratar sobre o tema foi a atuação do presidente da Câmara, mas na sequência o caso da morte do médico Jaime Gold ancorou emocionalmente a proposta em um caso, servindo para atestar empiricamente a suposição de que os adolescentes estariam “incontroláveis”.

Antes de partir para a apresentação das justificativas pelas quais o jornal apoia a redução da idade penal e as propostas de parlamentares, é importante conhecer a representação das medidas socioeducativas. Como o jornal foi muito repetitivo ao retratar apenas a medida socioeducativa de internação - não houve menção às medidas em meio aberto, e tampouco à medida de semiliberdade -, não será necessária a criação de um tópico específico para tratar sobre o tema.

Em dezenove oportunidades, foram realizadas críticas duras ao sistema socioeducativo, e em muitas vezes o jornal utilizou o termo Febem para referir-se às instituições socioeducativas. Esse termo foi inutilizado pelo Estatuto da Criança e do Adolescente, eis que adotado quando vigia no ordenamento jurídico brasileiro o Código de Menores (1929 e 1979). Durante a vigência dessa legislação, estava estabelecido que a Febem (Fundação Estadual para o Bem-estar do Menor) seria destinada para abrigar tanto os/as adolescentes que estivessem em conflito com a lei, quanto a criança ou o/a adolescente que estivesse em situação irregular (doutrina que regia o código anterior) (BRASIL, 1979).

Com o advento do ECA houve previsão para a distinção dos centros socioeducativos para os adolescentes infratores, e casas de acolhimento para crianças e adolescentes que estivessem em situação de abandono, justamente para fazer a separação entre crianças e adolescentes, visto que necessitam de cuidados diferentes. Teoricamente, pode-se afirmar que houve essa distinção, porém há indícios de que muitos centros socioeducativos possuem características que remetem ao aspecto da Febem, não efetivando o que prima a legislação vigente (BRASIL, 1990). O jornal, ao defender a modificação da idade penal, reconhece que os centros socioeducativos precisam de melhorias, eis que “as instituições de correição para os menores, são conhecidas como fábricas de marginais há pelo menos cinquenta anos” (O GLOBO, 2003c, p. 6).

Uma crítica referente às instituições é de que elas não educam e não ressocializam. Em duas oportunidades o jornal informou que as instituições para “menores” de São Paulo oferecem condições 
piores que muitos presídios paulistas, e se nas unidades de São Paulo a situação é essa, “imagina em cidades menos prósperas” (O GLOBO, 2004c, p. 6). No editorial “Além da idade”, para afirmar a situação dos centros em São Paulo, o jornal destaca como fonte o titular da Secretaria Nacional de Direitos Humanos, Nilmário Miranda. O jornal chama um especialista da área dos direitos humanos para afirmar que as situações das unidades de todos os centros do Brasil são precárias, o que é corroborado pelos dados do último Levantamento Anual do Sinase, devido à superlotação dos centros, precariedades da estrutura física e das escolas (BRASIL, 2017).

O jornal facilmente adere à ideia de que a medida socioeducativa de internação possui a dupla função punitiva e educativa. Por vezes, se sobrepõe a interpretação punitiva. Outras vezes, o discurso educativo é proeminente.

No editorial "Sem meio-termo", o jornal afirma que "os próprios delinquentes juvenis entendem que podem cometer qualquer crime; afinal, a punição mais pesada é de três anos em regime de reclusão” (O GLOBO, 2007f, p. 6). Refere-se à medida de internação como pena, e ainda mistura termos do direito penal com o sistema da infância e juventude.

A exigência por mudanças expressada pelo jornal não carrega consigo, porém, a explicitação de seu conteúdo. Em uma oportunidade, mencionou que os centros apenas colaboram para a reprodução da criminalidade, e que uma forma de acabar com isso seria uma reforma ampla em todas as instituições (O GLOBO, 2003d, p. 6). Uma mudança específica é trazida no editorial "Muito a fazer”, pois “as instituições que tratam do menor infrator também precisam ser reformadas. O espectro da FUNABEM ${ }^{5}$, sinônimo de violência e de deseducação, tem de ser afastado de vez das áreas que tratam dos menores” (O GLOBO, 2007a, p. 6) $)^{6}$.

Sobre a referência do jornal ao espectro da Fundação de Bem-estar do Menor (Funabem), é necessário explicar que essa fundação ingressou no lugar do Serviço de Assistência ao Menor (SAM) em 1964, e trouxe mudanças institucionais decorrentes do golpe militar:

Essa instituição não tinha o objetivo de assistir diretamente os jovens marginalizados, mas sim “o de pesquisar métodos, testar soluções, estudar técnicas que conduzam à elaboração científica dos princípios que devem presidir toda ação que vise à reintegração desses menores à sociedade” (BRASIL, 1976, p. 36 apud BUDÓ, 2013, p. 68).

\footnotetext{
${ }^{5}$ Segundo o artigo $5^{\circ}$ da Lei no 4513 de 1964 a Fundação Nacional do Bem-Estar do Menor tinha o objetivo de formular e implantar a política nacional do bem-estar do menor, fiscalizando e coordenando as instituições que executavam essa políticas de acordo com os seus princípios, as FEBEMs (Fundações Estaduais de Bem-Estar do menor) (BRASIL, 1964). ${ }^{6}$ Trecho retirado do editorial "Muito a fazer", esse título refere-se que somente a redução da idade penal, bem como a manutenção da idade penal, não iriam resolver o problema da insegurança pública, tendo muito o que ser feito, incluindo melhorias nos centros socioeducativos (O GLOBO, 2007a, p. 6).
} 
A função declarada pela Fundação se mostrou insuficiente para a política de segurança nacional, e teve a sua eficácia invertida, pois acabou institucionalizando mais e sempre os/as mesmos/as (BUDÓ, 2013). Quando o jornal se refere ao espectro da Funabem é no sentido de que existem nos centros socioeducativos esses aspectos, pois os adolescente estão privados de liberdade em grande quantidade, e em péssimas condições físicas, com mínimas condições de reintegração social.

A crítica do jornal foi que esse viés não deveria estar presente nas instituições socioeducativas, uma vez o ECA trouxe o caráter de sujeito de direitos a adolescentes infracionalizados/as, mas por ele ainda não ter sido incorporado na prática nos centros socioeducativos - eles não educam e acabam por gerar mais violência -, isso justificaria o jornal trazer para os seus editorais tais críticas. A partir dessa breve passagem pela medida socioeducativa de internação, é importante trazer as justificativas para a redução da maioridade penal que foram apresentadas pelo jornal.

\subsection{A LENIÊNCIA DO ECA AJUDA A CRIAR “MONSTROS”}

Desde o ano de 1996 e até meados de 2013, as justificativas do jornal para a revisão da idade penal são basicamente as mesmas. Como já verificado, o jornal justificou que a possibilidade de voto pelos adolescentes a partir dos 16 anos os capacitaria a serem responsabilizados:

A proposta mais popular é a da antecipação da maioridade penal dos 18 para os 16 anos. Argumenta-se, com razão, que em um mundo precoce como o de hoje em dia, em que o adolescente pode votar, ele também deve responder penalmente por seus atos (O GLOBO, 2003d, p. 6).

Mas a antecipação da maioridade penal corresponde também à constatação de que o jovem de hoje atinge a maioridade mais cedo. Parece ser fenômeno do mundo globalizado. Não por acaso, a sociedade aceitou com naturalidade o voto facultativo a partir dos 16 anos (O GLOBO, 2004c, p. 6).

Apesar de o jornal trazer essa justificativa, em algumas vezes ele menciona que a redução de forma isolada não resolveria o problema da insegurança pública. A redução aparece como uma possível solução, mas ao mesmo tempo se reconhece que acarretaria um agravamento do sistema penal:

A agenda da discussão precisa ser ampliada para além da controvérsia da antecipação da maioridade para 16 anos. Diante da precocidade que marca o mundo moderno, o bom senso aconselha a revisão. Mas a medida, isoladamente, é contraproducente. Terminará despachando para penitenciárias sem controle do poder público uma leva de jovens para serem adestrados na vida do crime. Trata-se, então, de se definir um projeto amplo de aperfeiçoamentos: do ECA, das instituições e também do sistema penitenciário. A 
dificuldade da tarefa não pode retardar o seu início. Não se pode continuar a tratar do assunto em espasmos, de crime em crime (O GLOBO, 2004a, p. 6).

O jornal aduz que os centros socioeducativos e o sistema penitenciário também precisam de melhorias. Aparecem também duas críticas: as falhas do sistema penal não podem retardar a redução; o debate da redução não deve se ater à ocorrência de atos infracionais graves. Para o jornal, a redução deveria ser votada com prioridade. A publicação reitera esse mesmo discurso nos anos de 2003 e de 2015, nos editoriais “Além da idade” e "Crise dos presídios não invalida redução da maioridade”, respectivamente.

No editorial "Problema maior" menciona-se que as “FEBEMs" também possuem uma situação precária, e que já ocorre a “diplomação na criminalidade nos centros” (O GLOBO, 2003d, p. 6). O questionamento implícito possível de ser retirado a partir dessa afirmação: por conta das “FEBEMs” também serem precárias e funcionarem a favor da criminalidade, por que não colocar adolescentes nos presídios (também precários)? A resposta é simples: já que não há melhorias nos centros, seria mais eficaz e rápido reduzir a idade penal. No editorial "Momento de rever”, o jornal afirmou que de todas as mudanças que o Estatuto necessita, “a redução é a mais óbvia e a que requer menos discussão” (O GLOBO, 2003a, p. 6). Esses dois posicionamentos apareceram justamente dias após o caso da morte do casal Felipe e Liana.

É também após a morte do casal Felipe e Liana, em 2003, e a morte do menino João Hélio, em 2007, que a leniência do ECA apareceu como principal empecilho na luta contra a “criminalidade”, sobretudo em razão do limite de três anos para a internação (O GLOBO, 2008a, p. 6). O discurso da impunidade é sempre trazido pelo jornal. No editorial “Fora da realidade”, da mesma maneira, afirma-se que os adolescentes são estimulados a entrar para o crime porque o Estatuto impossibilita a sua responsabilização (O GLOBO, 2014b, p. 12).

Esse argumento é falacioso ao deparar-se com o trabalho realizado pela antropóloga Débora Diniz no centro socioeducativo feminino do Distrito Federal. Após passar o período de um ano em contato direto com as reeducandas, a antropóloga concluiu que "o estabelecimento educacional para cumprimento de medida socioeducativa de internação é antes uma prisão que uma instituição pedagógica de transformação de projetos de vida” (DINIZ, 2017, p. 31). A autora chegou a essa conclusão após deparar-se com um ambiente cheio de regras e horários que as internas deveriam cumprir; um ambiente mais rígido do que qualquer outro estabelecimento prisional, já que estes não possuem regras, e muitos deles são controlados por facções criminosas (CENTRAL..., 2016).

Conforme o gráfico 1, entre os anos de 2004 e 2006 o jornal publicou apenas quatro editoriais, sendo que no ano de 2005 nenhum editorial foi publicado. Durante esse período, os 
editoriais tiveram cunho reducionista, porém, o foco foi o aumento da criminalidade e da impunidade, mesmo sem a utilização de fontes, o que diminui a credibilidade desse argumento trazido pelo jornal. Após a morte do menino João Hélio, o jornal apresentou, nos editoriais "Mais do que leis" e "Falsa solução”, críticas à Polícia, ao Judiciário, às penitenciárias e aos centros socioeducativos:

A Polícia se mantém incompetente e, em parte, corrupta; a Justiça, lenta, continua executando mal as sentenças; e as penitenciárias e muitas instituições para menores persistem no trabalho de formar bandidos mais perigosos. O resultado de tudo isso é a impunidade (O GLOBO, 2007c, p. 6).

Se há leis falhas, existe também um Poder Judiciário que não consegue aplicar com eficiência a legislação existente; uma polícia incapaz de fazer investigações e instruir inquéritos que evitem chicanas advocatícias; e um sistema penitenciário inqualificável, bem como parte das instituições responsáveis por tratar do menor delinquente (O GLOBO, 2007b, p. 6).

Nota-se que, após outro ato infracional grave, o jornal manteve seu posicionamento favorável, porém, sendo crítico ao afirmar que apenas a mudança das leis não é suficiente para garantir a segurança pública do País. Justifica-se então o porquê do título do editorial ser "Mais do que leis”. O jornal cobra não apenas a mudança da idade penal, mas também melhorias no Poder Judiciário, na polícia, no sistema penal e no sistema socioeducativo.

As justificativas trazidas nos editoriais permaneceram as mesmas, apenas incluindo que o ECA prevê mais direitos do que deveres, colaborando então com a impunidade (O GLOBO, 2013). É também mencionado no editorial “Ações integradas contra a criminalidade juvenil” o baixo nível escolar dos adolescentes apreendidos (O GLOBO, 2013c, p. 16).

Como houve muita repetição nos argumentos para a redução, foi elaborada uma tabela, na qual serão apresentados todos os argumentos e o número de ocorrências em que cada argumento foi mencionado pelo jornal nos editoriais:

Tabela 1. Argumentos apresentados pelo O Globo - número de ocorrências.

\begin{tabular}{lc} 
Argumento & O Globo \\
\hline O ECA gera impunidade & 17 \\
\hline O ECA não condiz com a realidade da segurança pública & 16 \\
\hline Os adolescentes são capazes de discernir sobre o certo e o errado & 21 \\
\hline O ECA é paternalista & 27 \\
\hline O Estatuto contém excesso de direitos e escassez de deveres & 15 \\
\hline Há um grande envolvimento de adolescentes com atos infracionais & 16 \\
\hline Muitos adolescentes estão envolvidos em atos infracionais violentos & 21 \\
\hline O ECA é ineficaz, pois o índice de reincidência é alto & 1 \\
\hline Pesquisas mostram que a população apoia a redução da maioridade penal & 2 \\
\hline Se adolescentes com 16 anos já podem votar, também já sabem distinguir o certo do errado & 7 \\
\hline Outros países permitem punir com mais rigor & 2 \\
\hline Há um aumento nas apreensões de adolescentes & 7 \\
\hline A leniência do ECA estimula a criminalidade & 22 \\
\hline Maiores aliciam adolescentes para serem acobertados & 6 \\
\hline Total de ocorrências & $\mathbf{1 8 0}$
\end{tabular}

FONTE: elaboração própria com base na pesquisa ao acervo do jornal O Globo. 
Os argumentos mais utilizados pelo jornal são o paternalismo do ECA e o seu estimulo à criminalidade. Esses dois argumentos vão ao encontro do discurso de que no Estatuto há mais direitos do que deveres. A crítica do jornal se dirige contrariamente ao que de mais inovador o Estatuto trouxe: a proteção integral, que assegurou aos adolescentes o caráter de sujeitos de direitos. Em suas reflexões, o jornal apresenta argumentos que remontam ao paradigma anterior, da situação irregular e, ao mesmo tempo, a uma leitura sobre a resposta estatal voltada a um direito infracional do inimigo. Sob o falacioso argumento da modernização, os editoriais escondem um retorno ao início do século XX e à objetificação dos adolescentes.

Afirmar que o ECA é paternalista, mas ao mesmo tempo dizer que houve um crescimento de apreensões dos adolescentes, é contraditório. Não pode haver um estimulo à criminalidade e ao mesmo tempo o número de apreensões aumentar. Falta senso crítico ao jornal quando ele utiliza esses argumentos. Afirmar que a maioria da população apoia a redução, sem ela ter o mínimo de conhecimento sobre o assunto, torna-se imprudente. Trazer à tona esse debate, sem o devido aprofundamento, apenas corrobora o senso comum e colabora para que todo objetivo da legislação seja em vão.

Ao longo de quase duas décadas, o posicionamento do jornal e a argumentação que o fundamenta foram sempre os mesmos. No próximo tópico serão apresentadas as propostas apoiadas pelo jornal.

\subsection{REDUZIR A IDADE PENAL É A PROPOSTA MAIS ÓBVIA E A QUE REQUER MENOS DISCUSSÃO}

A primeira proposta parlamentar apresentada pelo jornal O Globo foi no editorial "Mais do que leis”, publicado no dia 16 de fevereiro de 2007, logo após a morte do menino João Hélio. A proposta de emenda à Constituição é a do senador Tasso Jereissati (PSBD/CE), e outorga ao juiz ou a um conselho de juízes “o poder de excluir o delinquente juvenil da proteção do Estatuto da Criança e do Adolescente, em função do crime cometido” (O GLOBO, 2007c, p. 6). Ao fazer uma busca no sítio do Senado Federal, conclui-se que a referida proposta foi a PEC n 26, de 22 de maio de 2002, que alteraria o artigo 228 da Constituição Federal, acrescentando o § único, que estipularia os casos em que o adolescente poderia ser considerado imputável. A referida proposta foi arquivada em 12 de 
janeiro de 2011 por mudança de legislatura e não chegou a ser desarquivada pela iniciativa de qualquer parlamentar (BRASIL, 2002).

O jornal também se posicionou favorável ao Projeto de Lei nº 82/2008 (BRASIL, 2008), que visava considerar os antecedentes infracionais do adolescente em conflito com a lei mesmo após ele atingir a maioridade (O GLOBO, 2008b) ${ }^{7}$. O autor desse projeto foi o deputado federal Márcio França (PSB/SP). Esse posicionamento aparece em dois editoriais, e esse projeto de lei foi arquivado em 2014. O artigo 144 do ECA veda a divulgação e a utilização dos antecedentes infracionais sem a devida autorização judicial (BRASIL, 1990).

No editorial “Solução fácil” o jornal critica o Projeto de Lei n 333 de 2015, de autoria do senador José Serra (PSDB), que aumenta o prazo de internação de três para 10 anos (BRASIL, 2015): “deixar preso mais tempo um adolescente que tenha cometido algum crime em condições que em vez de garantir sua ressocialização, operam no sentido oposto, será não apenas inútil como contraproducente” (O GLOBO, 2004b, p. 13). Nesse editorial o jornal afirma que o simples aumento do prazo de internação - a "solução fácil” - em nada adiantaria se não houvesse reformas nos centros socioeducativos.

Outra proposta apoiada pelo jornal é a que possibilitaria a redução da maioridade penal para 16 anos, nos crimes hediondos e no crime de tráfico de drogas (O GLOBO, 2007f). Trata-se da PEC 171/1993, que, na oportunidade, havia acabado de ser aprovada pela Comissão de Cidadania e Justiça da Câmara dos Deputados, como foi mencionado pelo próprio editorial. A partir de então, o jornal começou a apoiar abertamente a PEC da redução da maioridade penal que estava em tramitação. Em 2012, o jornal apresentou no editorial “Menores no crime, reflexo de uma legislação paternalista” a proposta do senador Aloysio Nunes Ferreira (PSDB/SP), a PEC n 33/2012, como a mais adequada para a sociedade.

Essa proposta consiste em atribuir ao Ministério Público o poder para propor um “incidente de desconsideração da imputabilidade penal” para os menores de 18 anos e para os maiores de 16 anos. Como critério para a desconsideração da imputabilidade, deveria ser observado o ato infracional praticado (todos os contidos no artigo $5^{\circ}$, XLIII, da Constituição Federal) ${ }^{8}$, a reincidência múltipla (caso seja ato infracional equiparado ao roubo e lesão corporal grave) e o discernimento, que será

\footnotetext{
${ }^{7}$ Nos editoriais “Fonte inspiradora” e "Revisão necessária”, o jornal mencionou tal projeto e inclusive que, juntamente com a redução da maioridade penal, seria uma forma de combater a criminalidade que o ECA possibilita (O GLOBO, 2008a, 2008b).

${ }^{8}$ Dispõe o artigo 5, LXII, da Constituição Federal: “a lei considerará crimes inafiançáveis e insuscetíveis de graça ou anistia a prática da tortura, o tráfico ilícito de entorpecentes e drogas afins, o terrorismo e os definidos como crimes hediondos, por eles respondendo os mandantes, os executores e os que, podendo evitá-los, se omitirem” (BRASIL, 1988).
} 
averiguado de acordo com a conduta social (BRASIL, 2012). Essa proposta é mais ampla do que a PEC 171/1993, pois além de dar poderes discricionários ao Ministério Público, abrange mais atos infracionais.

No editorial "Fora da realidade”, o jornal mencionou que a proposta do senador Aloysio Nunes foi apresentada “inutilmente”, pois o parecer da Comissão de Cidadania e Justiça declarou a inconstitucionalidade da proposta em fevereiro de 2014 (O GLOBO, 2014a). Após a publicação do editorial, o senador Cássio Cunha Lima (PSDB/PB) solicitou o reexame da proposta, e, após o reexame da PEC pelo relator Ricardo Ferraço (PSDB/ES), ela foi aprovada pela Comissão (BRASIL, 2012). Observa-se que após a crítica do jornal pelo arquivamento da PEC, ela passou por nova avaliação e foi aprovada. De volta em tramitação, o jornal continuou apoiando-a, e no ano de 2015 (ano da votação na Câmara da PEC 171/1993) apresentou nove editoriais sobre ela, dos treze que foram publicados.

Observa-se que o teor da proposta do senador Aloysio Nunes é parecido com o da proposta do senador Tasso Jereissati, que fora arquivada em 2011. O jornal sempre apoiou a redução, e também que o Poder Judiciário e o Ministério Público tivessem poderes discricionários para reduzir a idade penal, observando os critérios estabelecidos. A proposta do jornal, diferentemente daquela do Estatuto, sempre consistiu na volta do menorismo e do paternalismo, para que o adolescente seja reduzido a um objeto, com o Poder Judiciário e o Ministério Público podendo decidir discricionariamente diante de diversos atos infracionais.

\section{CONCLUSÃO}

Este trabalho teve como objeto de pesquisa a análise das representações do adolescente autor de ato infracional, bem como das justificações e das propostas para reduzir a maioridade penal apresentadas pelo jornal O Globo. A partir da análise de 46 editoriais, no tocante à representação do adolescente infrator, o jornal reproduziu os estereótipos, identificando-os na pele do adolescente negro, pobre e do sexo masculino. Identificou a pobreza como causadora e indutora da violência, contribuindo à seletividade e ao etiquetamento que já existe na sociedade e nos centros socioeducativos. Essa prática faz retrocederem os avanços estabelecidos pelo Estatuto, que visou dar o caráter de sujeito de direitos a todas as crianças e adolescentes.

Quanto aos atos infracionais foi seletivo ao retratá-los em seus editoriais, dando a impressão de que os atos infracionais graves acontecem como regra e não exceção, criando pânico moral, como foi anteriormente abordado. Muitas vezes auferiu sobre o aumento da criminalidade, sem levar em 
consideração a cifra oculta que foi explicada, e tampouco a utilização de fontes. Também colaborou com a seletividade dos atos infracionais que geram internação nos centros socioeducativos.

Apenas a medida socioeducativa de internação foi tratada pelo jornal, e em algumas oportunidades ele a identificou como educativa, responsabilizadora e reintegradora, para constatar que o Estatuto não é efetivado nos centros. Ao apontar a medida de internação como pena, utilizouse de termos do sistema penal, e também manifestou que a medida não pune, devido ao período máximo estabelecido para internação. Torna-se contraditório o jornal criticar que as instituições socioeducativas ainda permanecem com o “espectro da Funabem”, uma vez que o jornal também colabora com esse espectro em seus editoriais, quando não utiliza os termos técnicos e reproduz a mesma seletividade que era permitida pela Situação Irregular.

Nas justificativas utilizadas para a redução da maioridade penal, o jornal foi bastante repetitivo, e muitas vezes mencionou o aumento da criminalização, porém sem utilização de fontes. As justificativas não evoluíram, e o jornal não se preocupou com o fato de as situações dos presídios serem prejudiciais a qualquer tipo de reintegração social.

Isso ficou evidente nas propostas apoiadas, todas elas semelhantes. O teor das propostas era menorista, pois dariam poderes discricionários ao Poder Judiciário e ao Ministério Público, novamente regredindo ao Código de Menores e ao paternalismo vigente na época. No compasso da movimentação política, o jornal O Globo claramente atuou como ativista político ou empresário moral, para usar a terminologia da sociologia do desvio (BECKER, 2008). Além de apoiar a proposta em tramitação, também apresentou a proposta do senador Aloysio Nunes como a mais adequada.

Ao fazer uma comparação com o jornal Folha de São Paulo, que, desde a vigência do Estatuto e até o ano de 2014, publicou somente dez editoriais, tendo como principal viés o aumento do prazo de internação para até dez anos (BUDÓ, 2015), o O Globo publicou mais que o quádruplo de editoriais, e, no ano de 2015, devido à votação da PEC 171/1993, publicou mais editoriais de cunho reducionista, para apoiar a aprovação da PEC. A redução foi solicitada de forma imprudente, desconsiderando que com a redução da idade penal haveria o crescimento da população carcerária.

O jornal em momento algum se preocupou com a proteção integral estabelecida pelo Estatuto. Ele apenas reproduziu estereótipos já existentes na sociedade, e de forma equivocada aumentou a sensação de impunidade, a qual não existe comprovadamente. A mídia como controle social informal, representada pelo jornal O Globo, foi considerada prejudicial aos avanços estabelecidos pela legislação vigente. 


\section{REFERÊNCIAS}

ALVES FILHO, Francisco. A autoria institucional nos editoriais de jornais. Alfa, São Paulo, 50, v. 1. p. 77-89, 2006. Disponível em: <https://goo.gl/fVAmyt>. Acesso em: 20 mar. 2015.

ANDRADE, Vera Regina Pereira de. Pelas mãos da criminologia: O controle penal para além da (des)ilusão. Rio de Janeiro: Revan, 2012.

ANITUA, Gabriel Ignacio. Historias de los pensamientos criminológicos. Buenos Aires: Del Puerto, 2006.

ARIÉS, Philippe. História social da criança e da família. Tradução Dora Flaksman. 2. ed. Rio de Janeiro: Zahar, 1981.

ASSOCIAÇÃO NACIONAL DE JORNAIS. Maiores jornais do Brasil. Disponível em: $<$ https://goo.gl/5js721>. Acesso em: 20 dez. 2017.

BARATTA, Alessandro. Criminología y sistema penal. Compilación in memoriam. Montevideo: B de F, 2004.

BATISTA, Nilo. Mídia e sistema penal no capitalismo tardio. Discursos Sediciosos: crime, direito e sociedade, Rio de Janeiro, ano 7, n 12 , p. 271-288, $2^{\circ}$ semestre de 2002.

BECKER, Howard S. Outsiders: estudos de sociologia do desvio. Rio de Janeiro: Zahar, 2008.

BOURDIEU, Pierre. Sobre a televisão. Rio de janeiro: Jorge Zahar, 1997.

BRASIL. Câmara dos Deputados. Proposta de emenda à Constituição no 171 de 19 de agosto de 1993. Altera a redação do art. 228 da Constituição Federal. Autor: Benedito Domingos (PP/DF). Redação alterada pela Proposta de emenda à Constituição $n^{0}$ 57/2011. Altera o art. 228 da Constituição Federal. Autor Andre Moura (PSC/SE). Disponível em: <https://goo.gl/XTpQ0>. Acesso em: 25 nov. 2017.

BRASIL. Constituição da República Federativa do Brasil de 1988. Disponível em: $<$ https://goo.gl/HwJ1Q>. Acesso em: 8 nov. 2017.

BRASIL. Lei ${ }^{\circ}$ 6.697, de 10 de outubro de 1979. Institui o Código de Menores. Disponível em: <https://goo.gl/De5yTN>. Acesso em: 11 nov. 2017.

BRASIL. Lei $n^{\circ}$ 4.513, de $1^{\circ}$ de dezembro de 1964. Autoriza o Poder Executivo a criar a Fundação Nacional do Bem-Estar do Menor, a ela incorporando o patrimônio e as atribuições do Serviço de Assistência a Menores, e da outras providências. Disponível em: <https://goo.gl/6fZ6uT>. Acesso em: 15 nov. 2017.

BRASIL. Lei $\mathbf{n}^{\mathbf{0}} \mathbf{8 . 0 6 9}$ de 13 de julho de 1990. Dispõe sobre o Estatuto da Criança e do Adolescente e da outras providências. Disponível em: <https://goo.gl/rXKd>. Acesso em: 11 nov. 2017.

BRASIL. Ministério da Previdência e Assistência Social. Fundação Nacional do Bem-Estar do Menor. O “menor-problema social” no Brasil e a ação da FUNABEM. Rio de Janeiro: MPAS, 1976. 
BRASIL. Ministério dos Direitos Humanos. Secretaria Nacional dos Direitos da Criança e do Adolescente. Levantamento anual SINASE 2014. Brasília, 2017. Disponível em: <https://goo.gl/6oBdtE>. Acesso em: 15 abr. 2017.

BRASIL. Senado Federal. Projeto de Lei $n^{0} 333$ de 02 de junho de 2015. Altera o Decreto-Lei $n^{\circ}$ 2.848 de 7 de dezembro de 1940 (Código Penal) e as Leis n ${ }^{\circ}$ 8.069, de 13 de julho de 1990 (Estatuto da Criança e do Adolescente), e 12.594, de 18 de janeiro de 2012 (SINASE). Autor: José Serra (PSDB/SP). Disponível em: <https://goo.gl/a3Y5YS>. Acesso em: 27 set. 2017.

BRASIL. Senado Federal. Projeto de lei $\mathbf{n}^{\mathbf{0}} 82$ de 23 de maio de 2008. Acrescenta parágrafo único ao art. 59 do Decreto-Lei ${ }^{\circ}$ 2.848, de 7 de dezembro de 1940 - Código Penal. Estabelece a obrigatoriedade de consideração dos antecedentes do agente infrator, relativos a medidas socioeducativas de internação. Autor: Márcio França (PSB/SP). Disponível em: <https://goo.gl/H1F8ZK>. Acesso em: 25 nov. 2017.

BRASIL. Senado Federal. Proposta de emenda à Constituição no 26 de 25 de maio de 2002. Altera o artigo 228 da Constituição Federal, para reduzir a idade prevista para a imputabilidade penal, nas condições que estabelece. Autor: Tasso Jereissati (PSDB/CE). Disponível em: $<$ https://goo.gl/cnfh56>. Acesso em: $10 \mathrm{dez} 2017$.

BRASIL. Senado Federal. Proposta de emenda à Constituição no 33 de 04 de julho de 2012. Altera a redação dos arts. 129 e 228 da Constituição Federal, acrescentando um parágrafo único para prever a possibilidade de desconsideração da inimputabilidade penal de maiores de dezesseis anos e menores de dezoito anos por lei complementar. Autor: Aloysio Nunes Ferreira (PSDB/SP). Disponível em: $<$ https://goo.gl/eM9RSC>. Acesso em: 8 jan. 2018.

BUDÓ, Marília De Nardin. A redução da maioridade penal na Folha de S. Paulo: da razão à emoção. Revista Eletrônica do Curso de Direito da UFSM. v.10, n. 1, 2015.

BUDÓ, Marília De Nardin. Mídias e discursos do poder: a legitimação discursiva do processo de encarceramento da juventude pobre no Brasil. 2013. 542 f. Tese (Doutorado em Direito) - Curso de Pós-Graduação em Direito, Universidade Federal do Paraná, Curitiba, 2013.

CAPPI, Ricardo. Pensando as respostas estatais às condutas criminalizadas: um estudo empírico dos debates parlamentares sobre a redução da maioridade penal (1993 - 2010). Revista de Estudos Empíricos em Direito, vol. 1, n. 1, jan., 2014.

CENTRAL: o poder das facções no maior presídio do Brasil. Dirigido por Tatiana Sager e codirigido por Renato Dornelles. Porto Alegre: Panda filmes, 2016, 86 min.

CHRISTIE, Nils. The ideal victim. In: FATTAH, E. (ed.). From Crime Policy to Victim Policy. Basingstoke: Macmillan, 1986.

COHEN, Stanley. Folk devils and moral panics. 3 ed. London and New York: Routledge, 2002.

COSTA, Ana Paula Motta. Os adolescentes e seus direitos fundamentais: da invisibilidade à indiferença. Porto Alegre: Livraria do Advogado, 2012.

CUSTÓDIO, André Viana. Direito da criança e do adolescente. Criciúma: UNESC, 2009. 
CUSTÓDIO, André Viana. Teoria da proteção integral: pressuposto para Compreensão do direito da criança e do adolescente. Revista do Direito, Santa Cruz do Sul, 2008. p. 22-43.

DINIZ, Débora. Meninas fora da lei: a medida socioeducativa de internação no Distrito Federal. Brasília: LetrasLivres, 2017.

FLAUZINA, Ana Lucia Pinheiro. Corpo negro caído no chão: o sistema penal e o projeto genocida do Estado brasileiro. Rio de Janeiro: Contraponto, 2008.

GALTUNG, Johan. Peace and Peace research. Journal of Peace Research, Vol. 6, No. 3 (1969), p. 167-191.

JEWKES, Yvonne. Media \& crime. London: Sage publications, 2004.

LAMENZA, Francismar. Os direitos fundamentais da criança e do adolescente e a discricionariedade do Estado. Barueri: Manole, 2011.

MIRAGLIA, Paula. Aprendendo a lição: uma etnografia das Varas Especiais da Infância e da Juventude. Novos Estudos, n. 72, jul. 2005, p. 79-98.

PAVARINI, Massimo. Control y dominación: teorías criminológicas burguesas y proyecto hegemónico. Buenos Aires: Siglo XXI Editores Argentina, 2002.

PRATT, John. Penal populism. London/New York: Routledge, 2007.

RIZZINI, Irene; BARKER, Gary. Promises Kept, Promises Broken: Recent Political and Economic Trends Affecting Children and Youth in Brazil. In: Globalization and Children Exploring Potentials for Enhancing Opportunities in the Lives of Children and Youth. New York: Kluwer Academic Publishers, 2004.

ROSA, Alexandre Morais da. Direito infracional: garantismo, psicanálise e movimento antiterror. Florianópolis: Habitus, 2005.

SANTOS, Juarez Cirino dos. O adolescente infrator e os direitos humanos. Discursos sediciosos: crime, direito e sociedade, ano 5 , n. 9 e $10,1^{\circ}$ e $2^{\circ}$ sem. 2000, p. 169-179.

SAVE THE CHILDREN. Every last girl: free to live, free to learn, free from harm. London: Save the children, 2016.

VERONESE, Josiane Rose Petry, RODRIGUES, Walkíria Machado. A figura da criança e do adolescente no contexto social: de vítimas a autores de ato infracional. In: VERONESE, Josiane Rose Petry, SOUZA, Marli Palma, MIOTO, Regina Célia Tamaso (Org.). Infância e Adolescência, o conflito com a lei: algumas discussões. Florianópolis: Funjab, 2001.

VERONESE, Josiane Rose Petry. Os direitos da criança e do adolescente: construindo o conceito de sujeito-cidadão. In: WOLKMER, Antonio Carlos; LEITE, José Rubens Morato (Org.). Os “novos” direitos no Brasil: natureza e perspectivas - uma visão básica das novas conflituosidades jurídicas. São Paulo: Saraiva, 2012. 
VERONESE, Josiane Rose Petry. Responsabilização estatutária ou responsabilização socioeducativa (sociopedagógica): fundamentos. In: VERONESE, Josiane Rose Petry; ROSSATO, Luciano Alves; LÉPORE, Paulo Eduardo. Estatuto da criança e do adolescente: 25 anos de desafios e conquistas. São Paulo: Saraiva, 2015.

WACQUANT, Loïc. Punir os pobres: a nova gestão da miséria nos Estados Unidos. 3 ed. Rio de Janeiro: Revan, 2007.

WAISELFISZ, Julio Jacopo. Mapa da Violência 2016: Homicídios por Armas de Fogo no Brasil. Rio de Janeiro: FLACSO/CEBELA, 2016.

YOUNG, Jock. A sociedade excludente: exclusão social, criminalidade e diferença na modernidade recente. Rio de Janeiro: Revan, 2002.

ZAFFARONI, Eugenio Raúl. A palavra dos mortos: conferências de criminologia cautelar. São Paulo: Saraiva, 2012.

ZAFFARONI, Eugenio Raúl. Em busca das penas perdidas: a perda de legitimidade do sistema penal. Rio de Janeiro: Revan, 1991.

ZAFFARONI, Eugenio Raúl. O inimigo no direito penal. 2. ed. Rio de Janeiro: Revan, 2007.

\section{REFERÊNCIAS DOS EDITORIAIS DO O GLOBO}

O GLOBO. Ações integradas contra a criminalidade juvenil. Editorial, 26 mai. 2013c, p. 16.

O GLOBO. Crime reforça pressão por nova maioridade penal. Editorial, 22 maio 2015a, p. 18.

O GLOBO. Rever o Estatuto. Editorial, 22 out. 2001, p. 6.

O GLOBO. Momento de rever. Editorial, 15 nov. 2003a, p. 6.

O GLOBO. Além da idade. Editorial, 19 nov. 2003b, p. 6.

O GLOBO. Ampliar o debate. Editorial, 22 nov. 2003c, p. 6.

O GLOBO. Ampliar o debate. Editorial, 22 nov. 2003d, p. 6.

O GLOBO. Problema maior. Editorial, 26 dez. 2003e, p. 6.

O GLOBO. Reforma ampla. Editorial, 8 jan. 2004a, p. 6.

O GLOBO. Solução fácil. Editorial, 30 jun. 2004b, p. 13.

O GLOBO. Passo a passo. Editorial, 2 ago. 2004c, p. 6.

O GLOBO. Muito a fazer. Editorial, 22 jan. 2007a, p. 6. 
O GLOBO. Falsa solução. Editorial, 13 fev. 2007b, p. 6.

O GLOBO. Mais do que leis. Editorial, 16 fev. 2007c, p. 6.

O GLOBO. Com realismo. Editorial, 24 fev. 2007d, p. 6.

O GLOBO. Constatação. Editorial, 28 abr. 2007e, p. 3.

O GLOBO. Sem meio-termo. Editorial, 15 jun. 2007f, p. 6.

O GLOBO. Fonte inspiradora. Editorial, 31 mar. 2008a, p. 6.

O GLOBO. Revisão necessária. Editorial, 21 jul. 2008b, p. 6.

O GLOBO. Cobrar responsabilidade. Editorial, 22 abr. 2013, p. 12.

O GLOBO. Fora da realidade. Editorial, 11 ago. 2014a, p. 14.

O GLOBO. Fora da realidade. Editorial, 22 set. 2014b, p. 12.

O GLOBO. Demandas a enfrentar. Editorial, 2 mar. 2015b, p. 14.

Felipe da Veiga Dias

Pós-doutorando em Ciências Criminais pela PUC/RS. Doutor em Direito pela Universidade de Santa Cruz do Sul (UNISC) com período de doutorado sanduíche na Universidad de Sevilla (Espanha). Professor da Faculdade Meridional (IMED) - Passo Fundo. Coordenador do Grupo de Pesquisa “Criminologia, Violência e Sustentabilidade Social”. Advogado. Email: felipevdias@gmail.com

Marília De Nardin Budó

Pós-doutora em Criminologia pela Universitat de Barcelona. Doutora em Direito pela Universidade Federal do Paraná com doutorado sanduíche na Facoltà di Giurisprudenza da Università di Bologna, na Itália. Professora adjunta no curso de Direito da Universidade Federal de Santa Maria (UFSM). Coordenadora do Grupo de Pesquisa "Poder, Controle e Dano Social”.E-mail: mariliadb@yahoo.com.br

Patrícia Silveira da Silva Acadêmica do $9^{\circ}$ semestre da Escola de Direito da IMED. Bolsista de iniciação científica pela FAPERGS. Integrante dos Grupos de Pesquisa "Poder, Controle e Dano social" e “Criminologia, Violência e Sustentabilidade Social”. E-mail: patricia_silva.7@hotmail.com 